\title{
Calculative practices, social movements and the rise of collective identity: how \#istayathome mobilised a nation
}

\author{
Matteo La Torre and Patrizia Di Tullio \\ Department of Economic Studies, University "G. d'Annunzio" of Chieti-Pescara, \\ Pescara, Italy \\ Paola Tamburro \\ Freelance Data Scientist, Rome, Italy \\ Maurizio Massaro \\ Ca' Foscari University of Venice, Venice, Italy, and \\ Michele Antonio Rea \\ Department of Economic Studies, University “G. d'Annunzio" of Chieti-Pescara, \\ Pescara, Italy
}

\begin{abstract}
Purpose - The Italian government addressed the first wave of its COVID-19 outbreak with a series of social restrictions and calculative practices, all branded with the slogan \#istayathome. The hashtag quickly went viral, becoming both a mandate and a mantra and, as the crisis played out, we witnessed the rise of the Italian social movement \#istayathome. This study examines how the government's calculative practices led to \#istayathome and the constituents that shaped this social movement.

Design/methodology/approach - The authors embrace social movement theory and the collective identity perspective to examine \#istayathome as a collective action and social movement. Using passive netnography, text mining and interpretative text analysis enhanced by machine learning, the authors analysed just over 350,000 tweets made during the period March to May 2020, each brandishing the hashtag \#istayathome.

Findings - The \#istayathome movement gained traction as a response to the Italian government's call for collective action. Thus, people became an active part of mobilising collective responsibility, enhancing the government's plans. A collective identity on the part of the Italian people sustained the mass mobilisation, driven by cohesion, solidarity and a deep cultural trauma from COVID-19's dramatic effects. Popular culture and Italy's long traditions also helped to form the collective identity of \#istayathome. This study found that calculative practices acted as a persuasive technology in forming this collective identity and mobilising people's collective action. Numbers stimulated the cognitive, moral and emotional connections of the social ties shaping collective identity and responsibility. Thus, through collective identity, calculative practices indirectly influenced mass social behaviors and the social movement.

Originality/value - This study offers a novel theoretical perspective and empirical knowledge to explain how government power affects people's culture and everyday life. It unveils the sociological drivers that mobilise collective behaviors and enriches the accounting literature on the effects of calculative practices in managing emergencies. The study contributes to theory by providing an understanding of how calculative practices can
\end{abstract}

(C) Matteo La Torre, Patrizia Di Tullio, Paola Tamburro, Maurizio Massaro and Michele Antonio Rea. Published by Emerald Publishing Limited. This article is published under the Creative Commons Attribution (CC BY 4.0) licence. Anyone may reproduce, distribute, translate and create derivative works of this article (for both commercial and non-commercial purposes), subject to full attribution to the original publication and authors. The full terms of this licence may be seen at http://creativecommons. org/licences/by/4.0/legalcode
Calculative practices and social movements

Received 29 August 2020 Revised 12 December 2020 6 March 2021 28 July 2021 Accepted 19 October 2021 
AAAJ 35,9 influence collective behaviors and can be used to construct informal networks that go beyond the government's traditional formalities.

Keywords Calculative practices, Collective identity, Collective responsibility, Cultural trauma, Popular culture, COVID-19, Social movement, Emergency, \#istayathome

Paper type Research paper

The toughest moment? When we started to see the count of deaths; when I dealt with the first deaths. Then, we touched a wound that would keep opening more and more.

From an interview with the Italian Prime Minister (2 April 2020)

\section{Introduction}

The role of accounting and calculative practices in managing disasters has been investigated extensively (Lai et al., 2014; Sargiacomo et al., 2014). For governments, accounting is a technology and a language through which programs are articulated and made operable (Miller, 2001), and we know it produces and transforms human activities and behaviors (Boedker et al., 2019). Yet, collective behavior in response to calculative practices has largely been overlooked in accounting research. Prior studies show that framing activities in accounting terms can create solidarity among people and can foster a dialogue and a mutual understanding between the victims of a disaster and the actors involved in its government (Lai et al., 2014). However, most of this research focuses on government actions, given that governments are the primary agents in managing disasters. What is overlooked is how people can mobilise themselves to action in response.

Such is the case with COVID-19, too. In this disaster, the accounting literature emphasises the vital function of calculative practices and accounting technologies played in helping the government to manage the crisis (e.g. Ahmad et al., 2021; Ahrens and Ferry, 2021; Andrew et al., 2021; Huber et al., 2021; Sargiacomo et al., 2021). The way governments used numbers to support their responses to COVID-19 was a great theme of interest in a recent special issue of the Accounting, Auditing and Accountability Journal (Leoni et al., 2021). However, what remains unexplored and a topic worthy of investigation is how accounting and calculative practices fit within popular culture and how they influence people's behavior (Jeacle, 2012). Exploring this brings a new way of seeing "modern governmentality" and understanding how accounting practices work within sites of popular culture where mass culture ground, such as, for example, websites, media platforms and television shows (Jeacle, 2012). Hence, this research adds to the scant literature on how calculative practices influence and fit collective actions and behavior by examining how the Italian people collectively reacted to the government's management of COVID-19.

The COVID-19 pandemic provides a unique context for exploring the government's calculative practices in managing disasters. Such was the scale of the actions needed to combat the crisis that it brings great insights into the limits of a government's ability to mobilise, coordinate and maintain collective actions. Furthermore, Italy was one of the first countries to experience an outbreak and was the world's guinea pig for social measures. The Italian government accompanied this first wave of social restrictions with the slogan \#iorestoacasa (\#istayathome). Within a few days, the hashtag had spread across the web, becoming both a mandate and a mantra of support for those who believed in a necessary new world order. This caused the rise of the social movement \#istayathome as Italy's way of facing the pandemic.

This study examines how government's calculative practices gave rise to \#istayathome and the social dynamics that shaped this movement. It contributes to the accounting literature on calculative practices in managing disasters by unveiling the sociological 
constituents of such collective behaviors and their relationships with government actions. Social movements are organised collective efforts to solve social problems (Rao et al., 2000). They are informal networks of individuals and groups sharing the same collective identities and engaged in political or cultural conflicts (Diani, 1992). Social movements have mobilised people for political actions, protests and to promote awareness of societal issues (e.g. \#BlackLivesMatter, \#Fridaysforfuture). Similarly, \#istayathome was a call to act together to face the COVID-19 emergency. Hence, by examining \#istayathome as a social movement, we not only provide empirical evidence into the way governments can mobilise people to manage the emergency. But, we also provide a rare glimpse into the power of people to help each other and the hidden dynamics that might cause them to band together.

Our analysis is framed by the social movement theory and the constituents collective identity (Diani, 1992; Foust and Hoyt, 2018; Morris, 2000). From this analysis, we find a fourphase sociology of how communities mobilise during emergencies that moves from the government perspective to the sociological motivations that drive people to act together (Polletta and Jasper, 2001). We employed passive netnography, text mining and interpretative analysis to analyse the 353,758 tweets spanning March 7, 2020 to May 23, 2020 that constitute \#istayathome.

Our findings reveal that a collective identity rose out of a cultural trauma. As such, Italy's popular culture and traditions worked as a pivotal factor in sustaining the social movement over time. It created a sense of collective responsibility, which reinforced the government's power through collective action. In turn, we found that calculative practices acted as a persuasive technology, which created the emotional, moral and cognitive reactions in the people that formed the collective identity grounding the social movement. These findings enrich the literature on the socialising effects of accounting and calculative practices (Lai et al., 2014) by shedding light on the collective behaviors and how a collective identity makes them effective. They provide novel empirical and theoretical insights into the mutual interaction between calculative practices and people's social life and collective behavior.

The article is structured as follows. Section 2 discusses the previous literature and the theoretical framework. Section 3 describes the research method. Section 4 presents the results, followed by a discussion to conclude the paper in Section 5 .

\section{Theoretical background and literature review}

\subsection{Calculative practices for governing disasters}

Accounting numbers and the calculations surrounding disasters has been a long-standing research area, as these are some of the constructs that inform and support policy and the subsequent actions government's take. Calculative practices are an inherent part of organising and constructing social and political realities (Boedker et al., 2019). In turn, numbers are a "shared language" that convey a sense of authority, objectivity, rationality and precision (Levay et al., 2020; Power, 2004). For this reason, they help to maintain social order and so have become one of the most favored mediums of governing individuals, groups and organisations (Vollmer, 2003).

This notion accords with most studies on governmentality, which typically show that calculative practices are used as a tool for formulating and implementing policies (Miller and Rose, 1990). Miller (2001, p. 395) says calculative practices are "intrinsically and irredeemably social." Overall, accounting and calculative practices are a technology of government - "a way to link together responsibility and calculation" and "create the responsible and calculating individuals" (Miller, 2001, p. 380). What Miller means to say is that calculative practices are generally effective at engendering responsibility in actors and this paves the way to explore their social interactions (Lai et al., 2014; Miller, 2001). Yet, Miller (2001) argues that the worthiest sociological interest in calculative practices lies in understanding their ability to alter the power relations between people and influence their actions. 
AAAJ

35,9

4

The sociological implications of calculative practices draw their most profound ground in the domain of governmentality. In this context, calculative practices are a means to shape people's conduct with power yet not through coercion (Jeacle, 2012; Miller and Rose, 1990). This view emphasises the links between accounting and popular culture, shifting focus to how calculative practices affect people's daily lives and their private spaces (Jeacle, 2012). In social emergencies and disasters, calculative practices can be pivotal for ensuring certain (collective) behaviors (Quarantelli and Dynes, 1977). However, despite widespread interest in understanding these sociological implications, most accounting scholars have turned their attention to understanding how calculative practices emerge; how accounting technologies change; and how they are used to govern extraordinary events (Sargiacomo, 2015). Their effects on collective behavior have been largely overlooked.

In disasters, new calculative technologies, also known as extraordinary accounting, are created to respond to the "perceived necessity to act, and a need to eventually phase out and terminate the intervention" (Sargiacomo, 2015, p. 68). Accounting inevitably surfaces as a key technology in managing disasters - especially in the recovery phase, where identifying the needs of victims, and funding and monitoring the progress of projects is vitally important. Some scholars argue that calculative practices have no place in disaster recovery, as they can give the illusion of control (Baker, 2014; Matilal and Adhikari, 2020). However, many demonstrate that accounting and calculative practices are a positive force in these endeavors in that they provide a reliable way to reconstruct the facts after a disaster (Cooper and Lapsley, 2021; Sargiacomo, 2015; Sargiacomo et al., 2014; Taylor et al., 2014; Walker, 2014). Accordingly, in response to crises and emergencies, the object of the calculations and the accounting technologies change, and new ones emerge to govern the crisis and the particular phases of the emergency.

These changes in accounting technologies are often driven by changing accountabilities between the accountor and accountee during an emergency (Lai et al., 2014). Despite the contended individualising effect of accounting and its potential to increase the distance between the actors, empirical research has revealed the potential of accounting to foster dialogue, to engage stakeholders and to socialise topics (Lai et al., 2014). For example, engaging people in calculating damages can create collaborations, mutual understanding and facilitate accountability (Lai et al., 2014). In this way, prior research acknowledges the sociological ground of accounting technologies and how calculative practices fit into the relationships between government and individuals. However, the accounting literature provides few empirical insights into mass-scale reactions to these practices by governments. Even further, the constituents' perspective, i.e. the subjects of the calculative practices, have barely received attention in empirical accounting research.

Even with the COVID-19 pandemic, which has fundamentally altered our daily lives over an extended period, the research perspective has often been that of the government's. Recent accounting literature on the pandemic corroborates the vital role of calculative practices in managing crises and their risks as they foster or undermine relief and recovery efforts (Padovani and Iacuzzi, 2021). It has been shown that governments have used accounting and numbers to both govern the pandemic and as a technology for classifying, identifying and monitoring virus-related risks (Ahmad et al., 2021). COVID-19 has given rise to new objects that need to be calculated, such as human beings, their vulnerabilities, their primary needs and accounting stands up as an incomplete technology for representing and reconstruct these things (Sargiacomo et al., 2021). In kind, scholars have questioned traditional accounting technologies, like government budgets, for their capacity to consider and inscribe the societal issues that the pandemic has amplified (Andrew et al., 2021). Thus, the recent accounting literature keeps alive a vivid interest in how governments have managed and governed the social and health emergency created by COVID-19 (Ahrens and Ferry, 2021; Huber et al., 2021). Yet, empirically understanding how calculative practices influence people and their 
behaviors thus remains a significant area of interest to be explored, especially in the COVID19 pandemic given its magnitude worldwide.

Numbers and calculations have been an inescapable part of the pandemic - more than a year later and every day all around the world, we still hear the catch cry of the number infected and the number dead (Yu, 2021). Now we add the number of immunised. Numbers and metrics of the pandemic are part of our everyday life. They fill our house and influence our daily behaviors. National leaders use numbers in their discourse to buy people in and to gain legitimacy for their ways of managing the COVID-19 outbreak (de Villiers and Molinari, 2021). However, little empirical knowledge explains how people have collectively reacted to COVID-19 and how they have supported the government's actions in coping with the emergency.

In this study, we examine how collective behavior on a mass scale can transpire in response to a disaster and the calculative practices imposed to manage it. Our subject is the Italian government's management of COVID-19, and the Italian people's conduct in response. COVID-19 is among the most impactful sociological phenomena in a century. It is testing the human race to either come together or to revert to our animal instincts of personal survival. In Italy, people came together under the hashtag \#istayathome. Our question is, what were the elements that conspired to bring this collective action about?

\subsection{Social movements theory}

Throughout history, social movements have paved the way for great research interest by sociologists and political scientists (see Abdul Reda et al., 2021; Amenta et al., 2010; Diani, 1992, 2013). Diani (1992, p. 1) defines social movements as "networks of informal interactions between a plurality of individuals, groups and/or organisations, engaged in political or cultural conflicts, on the basis of shared collective identities." As argued, the concept of social movements rose to differentiate itself from other forms of collective actions, such as interest groups, political parties, protest events and coalitions, so opening a new area of investigation and theorisation (Diani, 1992). Among the definitions of a social movement, there is agreement that social movements differentiate themselves by being collective and spontaneous. This works in contrast to institutional behavior, where a group of people with the same beliefs cooperate to change the social structure of a society (Diani, 1992). This collective action results in, and from, a shared collective identity and solidarity among participants (Diani, 1992; Rao et al., 2000).

Academic interest in social movements spans a wide variety of fields and disciplines, including accounting. For example, recent accounting studies examine how corporate disclosure mobilises collective actions and pressures (Islam and van Staden, 2018). McLaren and Appleyard (2021) examine the social movement as a new source of normativity in a changing organisational field, while Michelon et al. (2020) uncover the ideology of activism in shareholders. Recent research also demonstrates how a social movement like \#metoo can change the dynamics of accountability and its power relations (Goncharenko, 2021). The motivations behind such great recent interest in social movements can be found in the parallel changes to society's structure, where, today, people have more power to join together to act. They have more power to influence, and they are much more able to participate in political debate.

The new societal structure of the third millennium has in large part based on the ease with which social media allows us to form informal networks (Van Laer and Van Aelst, 2010). As Heimans and Timms (2018) explain, associations and democratised movements now have the power to mobilise mass social opinion and behavior at the stroke of a key. Social media platforms, such as Facebook and Twitter, give us a cheap and convenient way to communicate en masse instantly. As a result, we interact more, the distance between us is less, and top-down power networks that muster collective commitment arise spontaneously. 
AAAJ

35,9

6
Further, the magnitude of a social movement is a function of this so-called "new power" -a more democratised power of the people with an increased ability to participate, mobilise action and construct informal networks (Heimans and Timms, 2018). Diani (2000) argues that new communication technologies facilitated virtual social movements and online networks. However, online networks have only made an instrumental contribution to social movements. They can facilitate social ties, but they cannot replace them and cannot explain the sociological constituents of social movements (Diani, 2000). Van Laer and Van Aelst (2010) conclude that new media can neither create the activism necessary to mobilise collective behaviors nor stable enough social ties to instigate or sustain it. Thus, there is a need to go beyond people's virtual interactions to understand the motivating constituents of social movements.

In the same vein, Foust and Hoyt (2018) confirm this concern by arguing that Web 2.0 has caused a reductionist approach to enquiring into social movements, so highlighting their functionalist view. They point out that, while Web 2.0 and social media both help and hinder communications to mobilise resources and institutionalise social movements, "a social movement exists prior to the communication that creates it" (Foust and Hoyt, 2018, p. 38). To avoid this functional approach, the determinism of technology and techno-utopian and -dystopian visions, researchers need to amplify the constitutive meanings and identities of social movements in new communication mediums (Foust and Hoyt, 2018). In this study, we embrace this constitutive perspective by acknowledging the limits of social media and overlooking its mere instrumental function, and, instead, focusing on the sociological constituents of the social movement \#istayathome.

\subsection{The constituents of social movements and collective identity}

Collective responsibility, collective identity and cultural framing are common factors explaining the rise and development of social movements. Social movements involve cultural rituals and practices that provide a sense of belonging from which a collective responsibility can emerge (Brown et al., 2017; Saunders, 2008). Thus, while collective responsibility is a primary goal driving social movements, as explained below, it is grounded on and shaped by people's collective identity and culture.

2.3.1 Collective responsibility. Collective responsibility is defined as shared intentions and beliefs that coordinate the activities of multiple individuals (Bratman, 2014). Bratman's view of collective responsibility is inspired by a collectivist perspective on the common interest driving social movements. The rise of collective responsibility cannot be limited to sharing intentions between members. Rather, it requires acting together for a common purpose (Bratman, 2014). However, Bennett and Segerberg (2012) contend that people do not act together just because they share a common problem or goal, but a collective identity can also motivate their cooperation. Thus, prior research recognises collective identity as the broad concept underpinning collective responsibility and the component that shapes social ties in social movements (Brown et al., 2017; Saunders, 2008).

2.3.2 Collective identity. When people identify themselves within a group and its collective identity, cooperative behavior means a willingness to give up a personal action to preserve a collective good (Brewer and Gardner, 1996). In social movements, the individuals belonging to informal networks always share a distinctive collective identity (see, e.g. Diani, 1992; Foust and Hoyt, 2018; Van Laer and Van Aelst, 2010; Saunders, 2008). Polletta and Jasper (2001, p. 285) describe collective identity as "an individual's cognitive, moral, and emotional connection with a broader community, category, practice, or institution." Thus, collective identity is a multifaceted and abstract concept that is broadly applied to understand: why people join a collective action; how group cohesion develops; and why it supports collective actions over time (Flesher Fominaya, 2010). 
While Polletta and Jasper (2001) situate collective identity within the individual, other explanations of social movements see collective identity as a process or an output generated through collective actions (Flesher Fominaya, 2010). This perspective rejects the position that collective identity is given and already exists out there and, instead, focuses on its formation over the collective action (Flesher Fominaya, 2010). However, there is a shared acknowledgement that collective identification is both an end and a means in social movement (Jasper, 2011). Diani (1992) highlights this dual role of collective identity by arguing that it is the pre-existence of a collective identity that often distinguishes social movements from other forms of organised collective behaviors. He posits that, in social movements, the sense of belongingness and, therefore, collective identity exceeds the length of the collective public actions; collective identity also exists in its latent phase of social movement (Diani, 1992). Collective identity is, therefore, either "a precondition for the creation of new and different identities" and social movements, or a "persistent, though latent, basis for a new upsurge of mobilisation" (Diani, 1992, p. 16). Thus, collective identity may have multiple roles in social movements and be constituted in different ways (Foust and Hoyt, 2018). Nevertheless, our main interest remains its ability to mobilise collective actions and cohesion.

2.3.3 Cultural framing of collective identity. In line with Polletta and Jasper's definition, collective identity is influenced by moral, emotional and common cultural traits, which bring people to act together (Diani, 2000; Flesher Fominaya, 2010; Jasper, 2011; Morris, 2000). These elements are used and reflected in the cultural framing of social movements, as being the way to attract people support through their ideology, "disseminate their ideas into society and address the key issues faced by the people in ways that seek to garner membership" (Abdul Reda et al., 2021, p. 6). Collective actions are inspired and produced by cultural and emotional processes (Morris, 2000). By this, people participation in the collective action resonates in their individual and collective identity and make their action meaningful (Buechler, 1993). In this process, culture is the symbolic system for constructing meaning, and cultural framing is the way for the ideological articulation and constructing signification (Buechler, 1993). Thus, as Buechler (1993) concludes, constructing the collective identity cannot gloss over the culture that forms the identity, commonality and solidarity in social movements.

In social disasters and emergencies, a community can find these cultural and emotional processes in its cultural trauma. Kassem and Jackson (2020) note that collective identity can also result from a cultural trauma resulting from a disaster. Cultural trauma takes place "when members of a collectivity feel they have been subjected to a horrendous event that leaves indelible marks upon their group consciousness" (Alexander, 2016, p. 3). It is rapid, radical, exogenous and unexpected social change that impacts normal routines, causing a "wound to cultural tissue" (Sztompka, 2000, p. 458). People react to this trauma through solidarity and a desire to share their sufferings (Narveson, 2002; Stilz, 2011). Thus, extraordinary and negative events may construct a shared culture from suffering and build people's collective identification.

In this study, we look at social movements as a process through which collective identity is used and constructed to mobilise collective actions and collective responsibility. In doing so, we enquire into the constituent factors that frame and form collective identity. By employing this theoretical framework, we focus on the sociological factors that turned the Italian government's \#istayathome promotion into a social movement, united in the common goal to "get through the pandemic together." By this, we aim to unveil the elements of collective identity, if any, and how they can come together to shape collective responsibility in response to a government's calculative practices.

\section{Research methodology}

With the advent of the Internet, online communication and social media, scholars have often enquired into how online social movements develop (Abdul Reda et al., 2021; Brown et al., 2017;
Calculative practices and social movements 
AAAJ

35,9

8

Foust and Hoyt, 2018; Gerbaudo, 2012). Additionally, online communication provides scholars with easy access to data and gives the advantage of using automated methods for analysing text and data (Abdul Reda et al., 2021). The significance of social media in the accountability literature has also influenced accounting research, as it is providing a new place and a new means by which discourses on accountability are occurring (Jeacle, 2021). Social media and Web 2.0 have created a vast quantity of data and brought new complexities to data analysis as well. Accordingly, quantitative research approaches often reduce social movements to static overviews of protest activities (Foust and Hoyt, 2018). This has created the need to employ research methods that capture richer insights into the development of social movements and how they foster collective identity (Foust and Hoyt, 2018).

In response to this need, we employed the netnography methodology to examine the social movement \#istayathome. Netnography is a portmanteau of "Internet" and "ethnography" that makes the online world and social media its research site. Netnography is a set of research techniques for data collection, analysis and representation of symbolism, meanings and behavior patterns rooted in participants observation in digital communities (Kozinets, 2002). It offers scholars "a means of gathering data that are both rich in nature and potentially wide in scope" (Jeacle, 2021, p. 97). Therefore, to achieve this dual objective and avoid the risk of becoming reductionist with a quantitative analysis, we combined both quantitative and qualitative methods to analyse our data. In detail, we used unsupervised topic modelling to automatically analyse a large quantity of textual data coupled with interpretative analysis to ensure the human touch was not lost. This combination allowed us to get insights from both a large volume of data while revealing the overarching elements that formed the social movement \#istayathome.

Our netnography is passive since we observed the social movement online and collected data without engaging in the debate/phenomenon (Jeacle, 2021). As a first step, we identified Twitter as the research site and data source. While being only one of many social platforms, Twitter's content is generally acknowledged as a reasonable proxy of the socio-political arena and has been widely used for academic research (Bright $e$ t al., 2020). Further, it is a tool used to communicate risk to society during disasters (Kim and Hastak, 2018) and usually reflects real social activism (Brown et al., 2017). In any netnography or enquiry into social movements in social media, there is concern that online data does represent the physical reality of collective actions (Foust and Hoyt, 2018; Jeacle, 2021). However, in our case, online activities were the only means of the social movement's public expression, as the COVID-19 restrictions limited people's physical activities. Thus, \#istayathome could not be more than an online movement, and this provides our data with reliability (Jeacle, 2021).

Data collection started during the first phases of the COVID-19 emergency in Italy in March 2020. While monitoring the public debate and collecting data about the COVID-19 on Twitter for another project, we found the hashtag \#istayathome (\#iorestoacasa in Italian) increasingly trending over the first few days of the lockdown. We soon understood that a collective movement was emerging. We then began to monitor and collect all messages containing the \#iorestoacasa or \#iorestoincasa hashtags on a weekly basis. As Foust and Hoyt (2018, p. 42) point out, in the collective identity framework, "hashtags allow others to identify with, and perpetuate, the movement virtually." Accordingly, by gathering the messages containing the hashtag \#istayathome, we collected all the reasonable voices and actions of people joining the social movement. Thus, at the end of May 2020, from a dataset of more than 14 million messages on Twitter about COVID-19 in Italy, we had gathered 353,758 tweets containing the \#istayathome hashtag dated between March 7, 2020 (when the Italian lockdown began) and May 23, 2020 (close to the end of the lockdown).

To overcome information overload due to the large volume of data (Jeacle, 2021), first, we employed machine learning tools for text mining designed to handle big data and automatic coding. With the support of a data scientist, the data analytics process involved mining the 
hidden topics in the tweets with a Latent Dirichlet Allocation (LDA) topic model implemented in Python. LDA is one of the most commonly used algorithms for classifying short texts. It is an unsupervised approach that performs well with text strings that only contain one topic (Blei et al., 2003). Compared to mixture models, which have only one latent variable that belongs to a specific cluster, LDA assumes one latent variable for any single token/word (Hu et al., 2014). Thus, the LDA allowed us to analyse a considerable amount of textual data consistently and it found the latent topics characterising the text (Jeacle, 2021). Our topic modelling results returned 16 topics underpinning the tweets about the social movement \#istayathome.

The topic model's results were reviewed, discussed and endorsed by all the authors through an iterative process passing through analytics, raw data (tweets) and theory. To enhance reliability, we only considered the original tweets (165,654 of 353,758 tweets). This avoided any bias that might have been introduced by bots automatically retweeting the tweets of others. We interpreted the topics and named them after their most salient keywords. We then built an intertopic distance map coming from LDA to show how the topics are positioned along two dimensions and linked to each other (as shown in the next section).

The automated topic model provided insights into the linguistic symbols, labels and feelings constituting the social movement and its collective identity. It was the empirical interrogation of cultural labels and linguistic symbols that often allowed sociologists to enquire into collective identity in social movements (Brown et al., 2017). Thus, through linguistic analysis, we searched for how people label their actions, feelings and emotions, and how labels give them shape and direction in a social movement (Jasper, 2011). Therefore, after the topic modelling results, we analysed the tweets belonging to the topics in-depth by embracing a more qualitative and interpretative approach to deepen data and give them sense within the social movement and context of the COVID-19 emergency. Our deeper engagement with messages and raw data aims to explain further the deployment of the social movement's constituents according to the theoretical framework and their interactions and tension with calculative practices over time.

\section{Results}

Table 1 presents the list of topics and corresponding top salient keywords resulting from the topic modelling, while the intertopic distance map in Figure 1 shows the mutual closeness, size and distribution of each topic. The map is divided into quadrants reflecting the semantic closeness of the topics. Each of the quadrants exists on a scale from emergency conditions (left) to daily life (right) and from the digital realm (top) to the physical realm (bottom). From an interpretative analysis, we grouped the topics into four factors, as in as indicated by the boxed bold text. These four factors are the constituents of the \#istayathome social movement. We then placed each of the 16 topics along these two continuums.

Figure 2 presents the deployment of these four factors over time in terms of the number and frequency $(\%)$ of tweets. It also shows the daily number of infections and deaths to place the factors in the context of how the outbreak was developing and the severity of the emergency. Relying on these four factors and their deployment over time, we identified three stages in the development of the \#istayathome social movement. These were:

(1) The government's call for collective action (Phase 1) - enacted by the Italian government's campaign, calculative practices and social restrictions to manage the pandemic

(2) Mass mobilisation and the rise of collective responsibility (Phase 2) - occurred with the rise of collective action from the people forming the social movement
Calculative practices and social movements t 


\begin{tabular}{l} 
AAAJ \\
35,9 \\
10 \\
\hline
\end{tabular}

Table 1.

Latent factors, topics and keywords resulting from the topic modeling

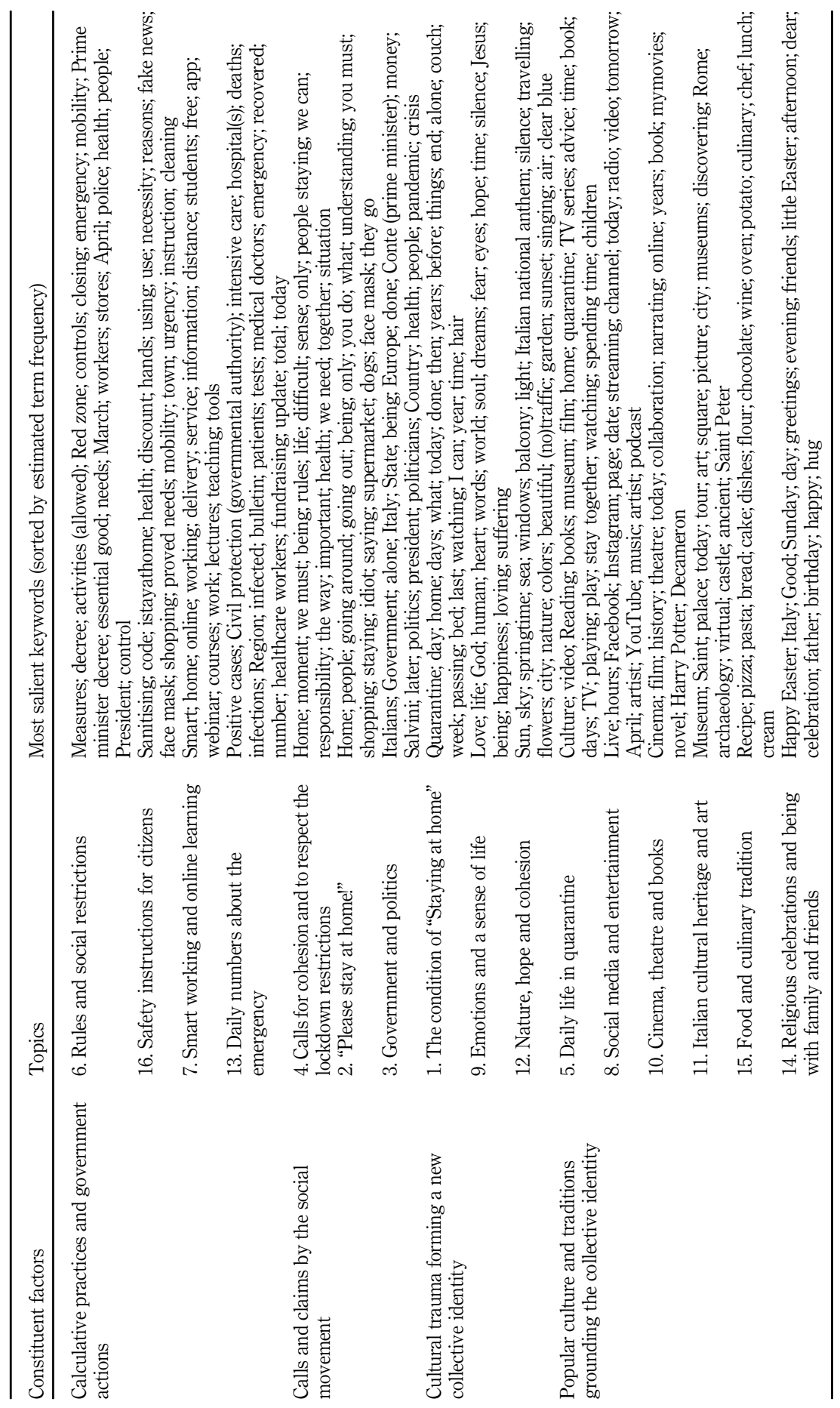




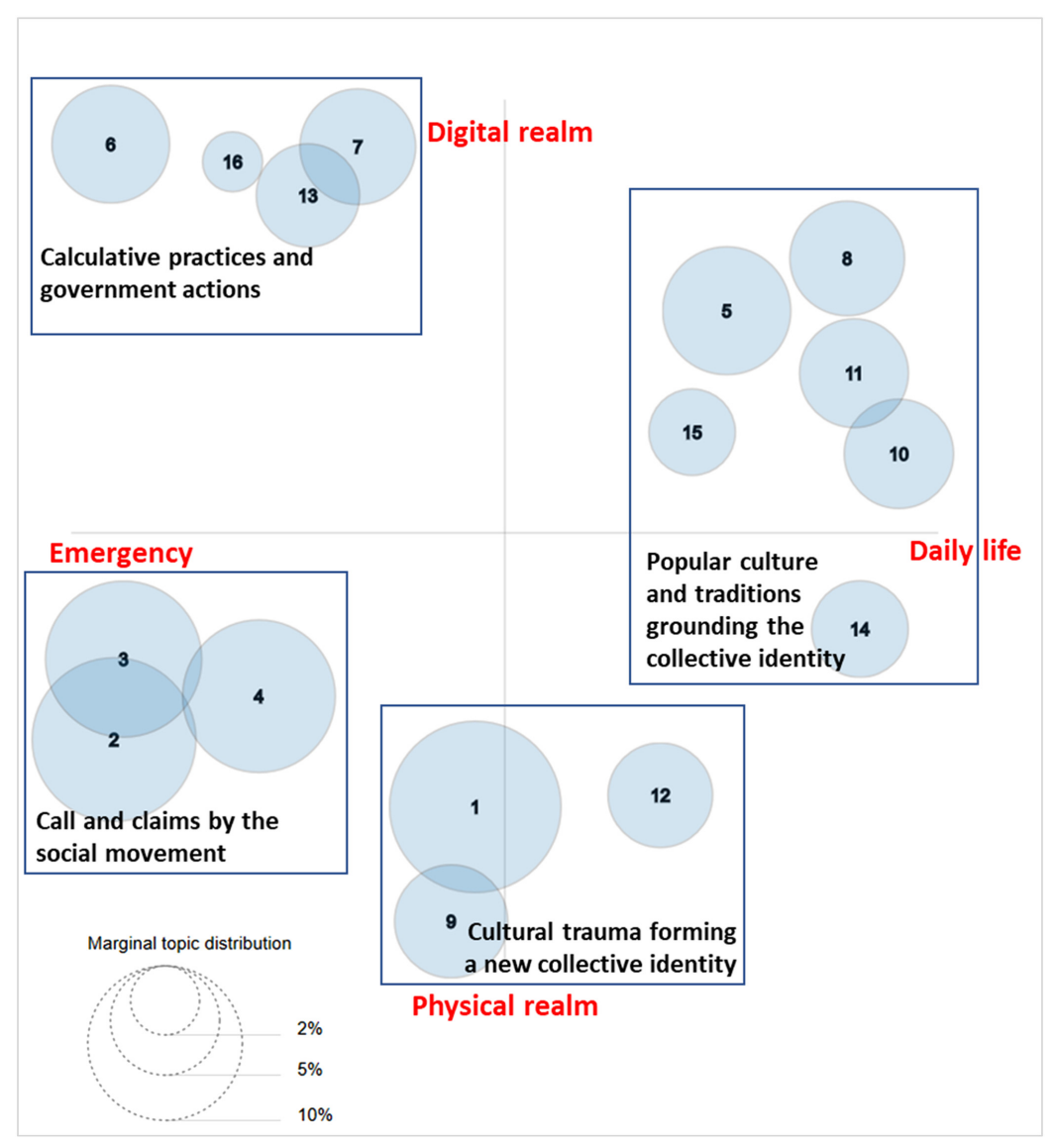

\section{Calculative practices and social movements}

Figure 1. Intertopic distance map of the topics and factors forming the social movement \#istayathome

(3) Cultural framing and the forming of a collective identity (Phase 3) - initially shaped by the cultural trauma of living through the acute phases of an emergency and, then, via a reawakening of Italian popular culture and its traditions

These phases explain the continuums of our theoretical framework - of daily life to emergency and connecting in the digital realms or the physical. It is worth noting that, as Figure 2 shows, these phases can work and coexist in parallel.

\subsection{The government's call for collective action: calculative practices and government actions}

In the Italian COVID-19 emergency, everything began on February 21, 2020 when the first infected person was found in Lombardy. More positive cases were subsequently found, and it became clear that the virus had started to spread. These early days were blanketed with a surreal and uneasy feeling that "there was no emergency" and that "all of this was not so serious before they began to count the number of contagions and deaths." By March 9, the infection count was so severe that the Italian Prime Minister announced the extension of lockdown nationwide. As reported by IlMattino (2020), the motivation was:

There is no time; we must change our habits. Data tells us that the infections, the hospitalised and the deceased are growing. 
AAAJ

35,9

12

Figure 2.

Deployment of the four factors that constituted the social movement \#istayathome over time

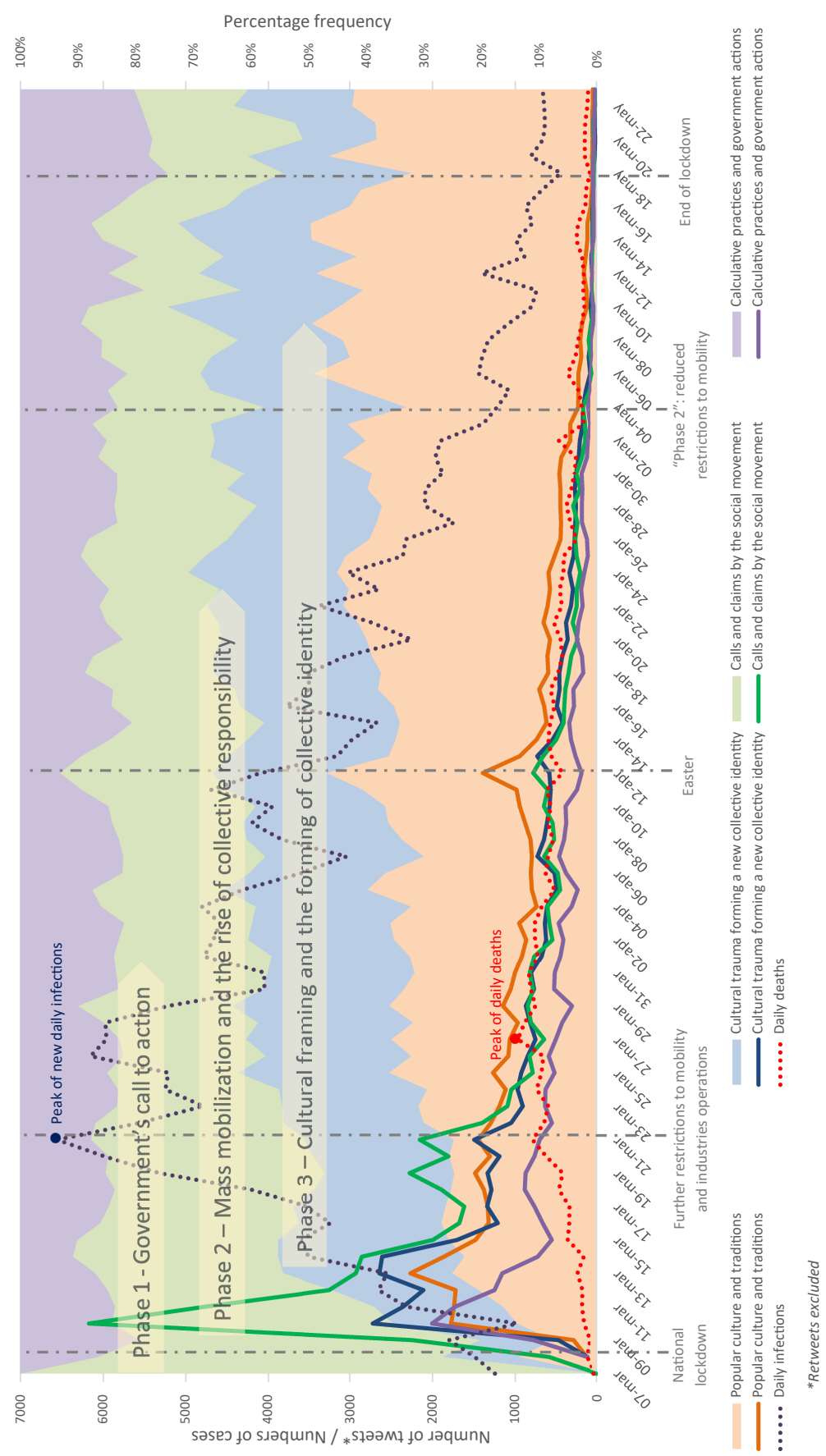


Thus, the Italian government made it clear that numbers were the basis of its decisions and actions to begin fighting the pandemic with a lockdown. The lockdown restrictions were designed to contain the virus's spread by seriously limiting people's movement and requiring them to stay at home. However, the measures were harsh, and citizens would have to commit and collaborate. Therefore, there was the need to engage citizens in the cause to get them to change their behavior, and the government would have to lead this change to get through the emergency.

Any social movement often has its root in events or champions to lead the call for people to mobilise in collective action (Buechler, 1993; Foust and Hoyt, 2018; Morris, 2000). We find this call in \#istayathome, the social campaign launched by the Italian government. When introducing the lockdown rules on March 9, Italian Prime Minister Giuseppe Conte wrote the following tweets:

The future of Italy is in our hands. Let's everyone do our part and renounce something for the collective good. The health of our loved ones, our parents, our children and our grandparents is at stake. I have just signed the decree \#istayathome

We can only win this battle with the engagement of EVERYBODY. Let's act responsibly. \#istayathome. Let take the virus out of our doors. Stay at home.

The campaign aimed to mobilise people into respecting the social restrictions and also to instil a sense of responsibility in supporting the nation to cope with the emergency.

In the factor "Calculative practices and government actions," we find more of the government's actions working in harmony with this philosophy of fostering new behaviors in people's daily lives. We also find more calls for people to take joint responsibility in these efforts. Messages about "Rules and social restrictions" (Topic 6) spread information about red-zones, local/national lockdowns, store closures, reasons for leaving home and controls to guarantee the restrictions would be respected.

\footnotetext{
金会Stay at home and avoid contact with others. You can safely meet other people, but only for essential needs, work and health. 憲 $\theta$

I Social distance for your health and for the sake of the others \& \#istayathome

\#Coronavirus: instructions for moving by car, on foot, public transport and for sports \#istayathome

The Decree in brief. Police inspections in train stations, airports and streets. Citizens must self-certify to prove their reasons for moving. Anyone who violates quarantine risks jail \#istayathome \#iremainathome \#covid19
}

Messages by government agencies, institutions (e.g. local governments, Regions and the Ministry of Health), and newspapers gave people instructions on how to behave during the emergency context and some of the changes they needed to make to their daily habits. "Safety instructions for citizens" (Topic 16) spread guidelines such as around when to use sanitising gel, or washing one's hands frequently, or when to ask for medical assistance:

If you have a temperature above $37.5^{\circ}$, are coughing or have breathing problems, stay at home. Do not go to the emergency room, but do contact your doctor. Contact the emergency medical service or the toll-free number provided for your region \#istayathome \#covid19italia

The restrictions also influenced the way people could work and how students could attend their classes through messages about "Smart working and learning" (Topic 7).

Smart working can make us both responsible and productive \#istayathome \#emergency 
AAAJ

35,9

These messages were intended to make people feel confident and comfortable with the new social order. They aimed to spread understanding of what was allowed and what was forbidden, but they also attempted to make people aware that combating the pandemic was up to them and how responsibly they behaved during the emergency.

Similarly, Topic 13 "Daily numbers about the emergency" sustained this need for collective action by reporting the daily counts of infections, deaths and patients in intensive care. Topic 13 is prominent in the "Calculative practices and government actions" factor. It shows how the government conveyed the sense of emergency through numbers. Messages like the following were constantly diffused through the media and tweets:

\#Covid19 Civil Protection emergency bulletin, Commissioner \#Borrelli: 2,857 hospitalised in \#ICU, 202 more than yesterday. Of the 42,681 patients, 17,708 are hospitalised with symptoms and 22,116 are in isolation.

These numbers were collected daily, and monitored and reported by the national Civil Protection agency. Every day, people waited for the 6 p.m. bulletin to hear these metrics.

Numbers helped make people aware and convinced them that the emergency was severe, as the following tweets representing people reacting to the numbers show:

Daily update: 10,149 infections, 8,514 currently positive (+619 than yesterday), 631 deaths (+168 than yesterday), 1,004 healed. Stay home, the situation is serious. \#istayathome

In terms of the number of infections, Italy has overtaken South Korea, with a worrying growth trend $(+1,492$ cases in one day). \#coronavirus \#istayathome

Latest daily bulletin: 1,247 new infections, 36 deaths. Unbelievable, we are getting worse day by day. [...] \#stayathome

For the government, the ideal outcome of the \#istayathome campaign was that every citizen would observe the restrictions and follow the instructions. However, introducing social restrictions was not always welcomed. Sometimes, it caused social tensions with those who did not believe in the need for these measures, as shown in the next phase. In response, the government introduced further restrictions. Numbers were used to reinforcing the state of emergency, along with the consistent call for further support and personal responsibility.

\#Coronavirus: 72 new cases in Veneto. Number of infections up to 670. \#Zaia [Veneto's governor], less talking, more action! \#istayathome

The situation is serious and is getting worse. Everybody must act with responsibility \#istayathome

@ ComuneMI, the infections are constantly growing. The city is at 359 infections: first peak. Don't mess around anymore: stay home. Let's all try to be careful and responsible \#istayathome \#wearein

These calculative practices were perpetuated throughout the emergency and through numbers that measured the outbreak's advance (see Figure 2). These numbers informed policy, the government's actions and influenced people's behavior all through the crisis. Thus, for the government, calculative practices acted as both a knowledge base and a persuasion device.

\subsection{Mass mobilisation and the rise of collective responsibility: calls and claims by the social movement}

Within a few days of its launch, the social campaign \#istayathome hashtag went viral. People promptly joined the government's voice, calling for everyone to act together to counter the emergency. The factor representing the "Calls and claims by the social movement" falls at the emergency end of the spectrum and is the people's response to the government's call to action (see Figure 1). As Figure 2 shows, this collective action became louder and, as it did, it became 
more effective at spreading the slogan \#istayathome and at sustaining the government's call for collective responsibility. The following tweets summarises the Italians' response:

Coronavirus. All of Italy has responded with \#istayathome. Franceschini [Minister for cultural activities and tourism]: a very important message for young people

In this message, we witness a mass mobilisation rising from the people - one which typifies this second phase - where the government's voice transforms into a collective action by the people. It was the emergence of a social movement - a call for action from people working towards a common goal.

Many Italian artists supported the cause and helped the government to spread the voice and mobilise people:

Coronavirus, the artists' appeal: 'Let's stay at home': \#istayathome, from Jovanotti to Sangiorgi [Italian singers] relaunching the campaign. Applause by Franceschini

Their appeals resonated on social media, and the news went so viral as to gain traction among citizens. This popular call for mobilisation was also driven by the pandemic metrics that kept portraying a worsening emergency:

\#Coronavirus: The sick are 6,387, 1,326 more than yesterday. 366 deaths and 622 cured. From \#Fiorello to \#Jovanotti [artists supporting the campaign \#istayathome with live shows], \#istayathome

In turn, people began using the metrics of the outbreak to support their own calls to respect the rules. For example:

Even today, 1,797 new cases of \#coronavirus and 97 deaths to add to the tally. \#istayathome and you must too

\#Coronavirus: 1,180 cases, 8 deaths in \#EmiliaRomagna. Intensive care patients are growing, they are 75, 11 more. Let's respect the rules! [... \# \#stayathome \#istayathome

These metrics helped make people aware that the emergency was severe and that it was time to act together. Thus, calculative practices acted as a cognitive technology to generate selfconsciousness in people. They helped people to engage and to convince others to respect the rules and stay at home.

We find this people's call for collective responsibility in two topics of the "Calls and claims by the social movement" factor. In Topic 4 "Calls for cohesion and to respect the lockdown restrictions," many of the tweets were messages encouraging cohesion, shared effort, and a respect for the life and health of others. Phrases like "we need," "we can," we must" are commonplace.

Let's fly the hashtag \#istayathome instead of Corona Virus and other terms. Never before have we needed such empowerment and positivity. For example, let's show WHAT WE DO AT HOME, whether it's watching a movie or reading.

We must stay at home, an easy task. An individual sacrifice to help Italy get out of this crisis. \#istayathome

The people's messages were driven by a collective responsibility that goes beyond their individual spheres. They often refer to the common good with symbols and terms referring to the whole collective, its health and safety - the human society they belong to.

Follow the rules for a common good: a slower spread of the \#coronavirus. If you do not want to do it for others, do it for yourself, your family, your friends. Be responsible, do not think you are the smartest. It's for life, for our civilization \#istayathome \#stayathome \#redzone \#milan
Calculative practices and social movements 
AAAJ

35,9

16

Just to be clear!! Let's respect some simple rules for the common good. \#istayathome \#everythingwillbefine \#coronavirus \#letsrespectrules

I am one of those who underestimated \#COVID2019 a few weeks ago, but I am changing my everyday life for everybody's common good. \#ItalyRedZone \#letsstayathone \#istayathome \#wholeitaly

Generally, people depicted the common good through the allegory of the nation, Italy, or through the action of helping others and, especially, those who were personally on the front lines of fighting the virus, i.e. the doctors and nurses. This harkens to a person's desire to collaborate and contribute to the national effort.

Let's help them to help us. \#istayathome \#coronavirus \#covid19italia

We have to stay at home. It's easy. A small sacrifice by every citizen to help Italy get out of this crisis \#coronavirusitaly \#coronavirus \#COVID2019 \#istayathome

We must collaborate. The virus is not dangerous for young people, but that is not the reason for us to do whatever we want. We must work together to preserve the weakest such as the elderly and people with pathologies. Therefore, \#istayathome \#stayathome

Thus, the rise of collective responsibility resulted in cohesion, solidarity and self-denial. However, this sense of responsibility did not involve everybody. We found tension and protest at the fringe of the social movement with complaints over the so-called "irresponsible people." The calls for people to stay at home and respect the lockdown gradually morphed from "invitations" to understand the gravity of the emergency into anger and grievances over people who flouted the rules. Topic 2, "Please stay at home!", contains these strong messages of anger, resentment and protest towards those who did not want to give up their lifestyles and habits.

Only today, we recorded 1,492 new cases and 133 deaths in Italy. The situation is serious. Let's put aside selfishness and follow the instructions to stem the spread of the virus! \#istayathome \#COVID19italia \#youareirresponsible

Which part of the phrase "you must stay at home" did not you understand? There is a DANGEROUS VIRUS that is slowly infecting the whole of Italy, I know it is difficult but, we MUST stay at home for OUR health and OUR loved ones!!! \#irresponsible \#istayathome \#coronavirus

Dedicated to those idiots who insist on travelling, doing house parties, dinners with friends ... \#istayathome \#coronavirusitalia \#redzone \#quarantene

Through these messages, people were attempting to change the actions and beliefs of others to align them with those who believed in the current collective action. However, contrasted the worsening emergency and the messages falling on deaf ears, these calls were often cast in exasperated and pleading tones:

Please stay at home. I am asking this with all my heart. We must ALL work together to overcome this virus, for us, for our family and especially for Italy. \#stayathome \#istayathome

Within a week of the lockdown, Twitter was awash with complaints over the upsurge of those flouting the rules and going out despite the rules. The social movement was resisting and persisting by establishing its voice.

Days and weeks go by, but people still "perhaps" fail to realise the gravity of the situation. Almost 3,000 deaths in Italy and 8,000 worldwide. Oh, they just cannot stay at home, IGNORANT SELFISH people. \#stayathome \#istayathome

Don't give up on communication, do not give up on messages to remind people that they need to stay home. Here it is enough to get distracted for a moment and everyone goes back around. Bombard people with messages, you must bombard them. 
The tensions between the "responsible" and "irresponsible" ones became intense with the increasing count of deaths and infections. These social tensions were also portrayed by political messages falling in Topic 3 "Government and politics." These are messages through which people participated in the political debate by supporting or critiquing the government's decisions, or simply thanking other countries for the aid they provided, e.g. Albania and China:

But tomorrow everyone at work and thousands of people will move. I understand that the nation cannot be stopped but we need further restrictions otherwise we will not get by \#istayathome \#coronavirus \#redzones \#closeLombardy \#stayathome \#COVID19

Italy and Albania: 2 nations, 1 heart. Thanks to our Albanian brothers, doctors and nurses!!! \#istayathome

In this second phase, the messages provided a great resonance to the government's voice in the early days of the lockdown. The collective action gave momentum to \#istayathome, the rise of collective responsibility, and the citizens' commitment. This mass mobilisation resulted in the spontaneous construction of an informal network of people having the same beliefs and cooperating with the same goal (Diani, 1992) - in this case, to stop the virus from spreading. These shared intentions coordinated people's collective activities in support of preserving a common good (Bratman, 2014). Solidarity and collective responsibility were, at once, the drivers of the people's mobilisation as well as its purpose (Brown et al., 2017). Broadcasting the metrics of the pandemic was a calculative practice to raise awareness of the emergency and the need for collective action. However, what we found in "Calls and claims by the social movement" represents only the claimed intention of the mass mobilisation and the most evident purpose of the social movement. Accordingly, this factor does not fully explain how a collective identity was formed and how it underpinned the social movement \#istayathome. For this, we must look to the cultural factors that brought people to act together and the third phase of the movement.

\subsection{Cultural framing and the forming of a collective identity}

Collective identity is more than just a driver of collective actions; it is both an end and a means in a social movement (Diani, 1992; Jasper, 2011). In the \#istayathome, we found both an existing collective identity motivating people to act together and the creation of a new one coming from the social movement and outbreak experience. According to Diani (1992), a social movement can form from an existing collective identity or it can be brand new. This process depends on the cultural framing of the community and the moral, emotional and common cultural traits that have brought the people to act together (Diani, 2000; Flesher Fominaya, 2010; Jasper, 2011; Morris, 2000).

The "Call and claims by the social movement" factor represents the most evident claims, requests and slogans from the people's collective voice, but these voices subsided after the early weeks of the emergency, becoming less vivid than other factors in the acute phases of the pandemic. What followed would come to typify the social movement's collective identity (see Figure 2). In the third phase of the \#istayathome, we find that the extraordinary collective experiences of COVID-19 and the resurging of the Italian people's identity, culture and traditions created a collective identity. This phase spans the remaining two factors of the movement: "Cultural trauma forming a new collective identity" and "Popular culture and the traditions grounding the collective identity."

4.3.1 Cultural trauma forming a new collective identity. In disasters and social crises, emotional and cultural processes are significant in constructing meaning and collective identity. Cultural traumas create cohesion among people as traumatic experiences reinforce a sense of being part of a broader community (e.g. Alexander, 2016). The COVID-19 emergency 
AAAJ

35,9

18

and its negative events constructed a shared culture from suffering that coalesced into a built citizenship. What we found in the messages belonging to the factor "Cultural trauma forming a new collective identity" was a kind of cultural trauma and the beginnings of the fundamental elements that had people make a decision between whether to come together or say instead that it's every man for themself.

Cultural trauma had been increasing since the early days of the lockdown, but it took on a more significant role in sustaining \#istayathome when people started to experience the more dramatic aspects of the emergency during its acute phase (see Figure 2). "The condition of staying at home" (Topic 1) was an important part of this trauma. The pandemic impacted people's daily lives in such a way as to impose dramatic and unusual conditions on them. Once busy, social, and useful, many people were forced to spend their time lying in bed or on the couch. We can see examples of people's desperation and frustration in the messages below:

Are we desperate enough? My neighbour has just screamed "It is like being in jail!" \#istayathome

I want to cry. I hope all this ends soon \#istayathome \#coronavirus \#COVID19Italy

I could sleep for a couple of hours. For a couple of hours, nobody talked to me about the virus. I want my life back \#istayathome

Being forced to stay at home, sometimes alone and far away from friends, family and loved ones was a negative experience for many. In addition, hearing constant negative news about the increasing numbers of deaths instilled a shared feeling of suffering and discomfort.

Numbers contributed to constructing the dramatic reality of the emergency. Death counts became symbols depicting the emergency just as vividly as dramatic scenes like the queue of military tanks carrying coffins at Bergamo.

Coronavirus in Lombardy, 17,713 infections in 24 hours, 319 deaths. In Bergamo, the army transports coffins to crematory ovens in other regions because the cemeteries are full \#istayathome

A hecatomb. Every day at 6 pm [when the daily numbers were announced]. \#istayathome

I cannot bear all these numbers about infections and deaths. . I cannot anymore. Can we get this data every three days, please? I understand \#istayathome. But show me now some nice things now. Thanks.

Once again, calculative practices and the numbers about the outbreak triggered people's emotional reactions to the worsening emergency. They created the sense of gravity and the collective emotions that underpinned the Italian cultural trauma.

250 deaths in one day. It is not a flu, this is a bloody war. \#coronarvirusitalia \#coronavirus \#istayathome

Topic 9 ("Emotions and the sense of life") embodies these emotional reactions. Here, people talk of reflecting on their sense of life, the eerie silence in the streets, and metaphysical topics like the soul, spirituality and religiousness.

\#istayathome and pray. Sometimes with dread, sometimes with gratitude, sometimes to reflect on myself $[\ldots]$

Sometimes, we lose hope and think it's the end ... But stop for a moment, breathe and remember ... It's just a bad time, it will pass! \#istayathome

We cannot overcome fear easily \#istayathome

These emotional reactions lay in hope and fear. Some found comfort in their faith, while others found faith for the first time. Through all these messages, we felt indications of a national cultural trauma for Italians. 
Hope that everything would be fine was found in the beauty of nature, the springtime, the sun and the sea (Topic 12 - "Nature, hope and cohesion").

The sight of a slice of sea comforts me. \#istayathome

Nature advances, the cherry tree is in bloom \#istayathome

The first flowering trees remind me that it is almost springtime, and like winter, nothing can stop it, not even this damn virus will stop my beautiful Italy, which will bloom again more beautiful than before! \#istayathome

Cultural traumas create cohesion among people as traumatic experiences reinforce a sense of being part of a broader community (Alexander, 2016). In Italy, this collectiveness manifest as actions of fellowship, such as singing the national anthem from balconies.

Hug me tighter. Naples sings on the balconies \#letstayathome \#stayathome \#istayathome

... meanwhile the tricolours [of the Italian flag] appear on the balconies \#istayathome

Singing on the balcony was a means of reducing distance, restoring social contact, and feeling as though one was a part of a community fighting together.

Music resounds in the air, notes walk in the breeze, different sounds but all sounds of hope, and on the balconies that I have always seen closed, people looking out. The virus takes us away from embraces but perhaps brings us closer in souls. \#coronarvirusitalia \#Covid_19 \#istayathome

\#Coronavirus. Exorcise fear, cancel distances, feel part of a whole. These are the reasons that push citizens in these days of \#istayathome to open the windows, to go out on the balcony

Thus, the people of Italy found national cohesion from symbolic action and the linguistic use of metonymy. They found that the parts, the people, came together to stand for the whole-Italy, its cities and its countrysides. Metonymy can turn subjective phenomena into objective facts (Green and Li, 2011). Thus, through metonymy, the Italians turned cultural trauma into symbolic objects - balconies, the national anthem, the Italian flag. People identified themselves within the cultural trauma they were experiencing, and this contributed to shaping a new collective identity that sustained \#istayathome in the acute phases of the emergency.

4.3.2 Popular culture and traditions grounding the collective identity. In addition to cultural trauma, we find that "Popular culture and traditions" was an essential factor in constructing the collective identity that sustained the \#istayathome social movement. While cultural trauma shaped a new collective identity, it also prompted Italian people to revisit their culture. These messages speak of discovering and rediscovering the Italian culture and traditions, often mixed with new virtual ways of experiencing them, as well as modern distractions. These experiences characterise the "Daily life in quarantine" (Topic 5) and were about activities and tips for how to spend time while staying at home:

Some tips to pass the time faster in this challenging period \#istayathome \#westayathome.

\#COVID2019 emergency, let's launch the hashtag \#ireccomendamovie: to face these difficult days and pass the time, what is better than seeing a good film? \#coronavirus \#istayathome

What to do in \#quarantene? Here are some tips on some social events and what not so as not to get discouraged by \#coronarvirusitalia! \# covid_19italia \#istayathome

It is within this topic that we also found messages from famous people supporting the \#istayathome social campaign:

Coronavirus, the world of culture is mobilised: \#istayathome campaign starts. Many personalities from the world of entertainment and sport join the \#istayathome campaign
Calculative practices and social movements 
[Dolce \& Gabbana]: Art, strength, hope, solidarity. Italy turning difficulty into creativity, as seen in these days by Aldo Cicchini. \#eveythingwillbefine \#istayathome \#italianproud

The Italians stuck in their homes go out and sing from their balconies the songs of the Italian tradition. It is almost the same feeling of winning the World Cup in 2006. You are SPECTACULAR, you are THE HOPE. \#istayathome \# COVID19 \#coronarvirusitaly

All the messages in this group of topics were encouraging and reflect the most hopeful stream of the social movement. They were messages aimed at alleviating the frustration and the unfavorable conditions people were living in while still convincing them to stay at home.

The activities in which the Italians found their social connections were varied. We divided them into the following topics, ranging from the most modern popular culture to the older, more traditional pastimes:

(1) "Social media and entertainment" (Topic 8): People filled their days with TikTok, Facebook and Instagram. Digital and social media tools were also a means to feel closer to each other. They were also the means through which artists performed their exhibition and entertainment for people at home:

My call to sportsmen, musical academies, chefs, songwriters, artists ... to all citizens. Share the passion, talent and culture for a new Spring on social networks \#istayathome

(2) "Cinema, theatre and books" (Topic 10): It was the same for cinema and theatre, too. Discovering the pleasure of reading books, watching cult movies alleviated the boredom and melancholy.

By popular demand on Italia1 [TV channel], the Harry Potter saga returns! Tonight, we leave for Hogwarts with \#HarryPotter. The appointment is at platform 93/4 every Monday and Tuesday. \#istayathome \#HarryPotter

An all-Italian artistic short circuit: \#MadamaButterfly by \#Puccini illustrated by Leopoldo \#Metlicovitz, with the musical and the graphic part. A story yet to be written in detail.

(3) "Italian cultural heritage and art" (Topic 11): Some took the time to rediscover Italy's artistic and cultural beauties, such as cities, museums, castles, squares as digital tours. In the Italian art and culture, some Italian people discovered hope and the feeling of belonging to a community.

The marathon continues: CULTURE DOESN'T STOP! [...] Every day new videos to tell the story of \#italianmuseums. Sign up, watch and share! \#istayathome

Let's admire the world and the Italian artistic beauties while sitting on the sofa comfortably. Discovering Piacentino \#istayathome

(4) "Food and culinary traditions" (Topic 15): Italians indulged in their culinary traditions by homemaking traditional recipes, such as pizza, pasta, cakes and bread. This was a way to find connections with the broader community - a way to feel Italian.

Today I am making tortellini, ravioli and fettuccine. All strictly homemade \#istayathome \#COVID2019 
\#istayathome and prepare the \#giudia artichokes with olive oil from \#puglia because \#ieatitalian

Thus, Italian people found their collective identity and the feeling of being Italians in their culinary traditions, cultural heritage and arts.

The cultural framing of \#istayathome was also influenced by contingent events over the emergency. Easter occurred over the lockdown. Unable to attend religious ceremonies or celebrate with family and friends, people discovered new ways of celebrating holidays. The messages in "Religious celebrations and being with family and friends" (Topic 14) and experienced unusual feelings around Easter and other celebrations like Father's Day:

\#Easter is coming, and we will not easily forget it ... After Good Friday, we await the Resurrection \#istayathome

Happy Easter everybody. \#wewillgetthrough if \#istayathome

Thus, the hope that people found in the Easter time and the Italian traditions characterising the daily life over the lockdown resonates in the social movement and enhanced solidarity and cohesion.

We found the same hope and solidarity in the messages reacting to the calculative practices and numbers occurring over the latest phase lockdown:

Let's keep it up! Let's make the curve of infections go down even in Easter and everything will be fine! \#istayathome

The other face of the \#italians $\$$ More than one hundred volunteers in a few hours \#solidarity \# distantbuttogether \#istayathome

Today's bulletin is encouraging and testifies our great job. Solidarity is also great: fundraising exceeds 63M. We have done our part \#togheterwewillgetthrough \#istayathome

Thus, "Popular culture and traditions" contributed to feeding the collective identity and a sense of cohesion during the emergency. This factor gained significant importance in the latest emergency phase and contributed to maintaining the \#istayathome social movement alive longer (see Figure 2). Relying on the Italian popular culture and traditions was a means to mobilise people and to revive the Italian collective identity. This latter result was a preexisting but latent collective identity in Italians that was rediscovered during the emergency (Diani, 1992). In turn, people joining the \#istayathome social movement used messages about their popular culture and traditions to disseminate their ideas into society and attract other people (Abdul Reda et al., 2021). Through this cultural framing, they used the symbolic system of the Italian culture to construct meaning, signification and articulate the \#istayathome social movement (Buechler, 1993).

\section{Discussion and conclusion}

Calculative practices by governments can be a powerful tool for inducing changes in collective behavior (Boedker et al., 2019; Vollmer, 2003). This study demonstrates how the government's actions and calculative practices can merge with, and even depend on, the active role of citizens in a state of emergency. We found that the \#istayathome social movement developed through three main phases: the government's call for collective action; mass mobilisation arising from collective responsibility; and a cultural framing that forged a collective identity. Calculative practices had a significant role in shaping and stimulating each of these phases and their constituent factors.

We find confirmation that the calculations for measuring the advancing outbreak contributed to making the Italian government and the people aware that the emergency was severe (Antonelli et al., 2021). Accounting influenced people's behavior, and numbers were
Calculative practices and social movements 
AAAJ

35,9

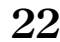

used to justify the government's prerogative for a state of exception (Antonelli et al., 2021). Thus, those calculative practices acted as a cognitive technology for the government's actions. However, they also extended their effects toward sustaining the social campaign and mobilising people's collective actions.

Calculative practices fostered mass mobilisation and the rise of people' collective responsibility. As the \#istayathome movement grew, the government's calls for collective responsibility were rapidly amplified by the voice of people. The Italian government wanted the people to do their part in stopping the spread. As their solidarity grew, action for the greater good supplanted self-serving behavior, as evidenced by the scorn given to those who did not respect the restrictions. In this collective action, calculative practices were a pivotal driver in generating collective responsibility. Numbers brought out a self-consciousness in people and they were used to engage and convince others to respect the rules. In so doing, calculative practices generated shared intentions and beliefs that mobilised people in their collective action toward a common purpose (Bratman, 2014; Brown et al., 2017). Thus, the government's calculative practices were a constituent factor in forming this movement, so corroborating their function of creating a sense of collective responsibility, awareness and solidarity among people (Lai et al., 2014). This solidarity resulted in cooperating to preserve a common good (Brewer and Gardner, 1996) - the health and safety of a collective, and the construction of informal networks of people having the same beliefs and goals (Diani, 1992).

While mass mobilisation and a popular call for collective responsibility are the most public expression of the \#istayathome social movement, we find that collective identity explains why people act together and join a social movement (Flesher Fominaya, 2010). Over the acute phases of the pandemic, with the peaks of infections and deaths, collective identity became significant in sustaining the movement and keeping it alive until the end of the emergency. Such a collective identity was latent in the early stages but dominant in mobilising the collective action. Diani (2000) argues that informal networks operate at their best when they are backed by real social linkages in localised communities, and this was definitely the case with \#istayathome. The \#istayathome social movement was substantially perpetuated by a coming together of the Italian people through their collective identity and its cultural framing. The collective identity grounded in \#istayathome was generated by the Italians' cultural trauma and their popular culture and traditions.

Like other studies (Alexander, 2016; Sztompka, 2000), we found that cultural trauma emerged as one of the main factors in creating a new collective identity. In turn, this cultural trauma emerged from the dramatic effects of the COVID-19 emergency and the situations the disease placed people in. In the Italian case, this trauma manifest as negative emotions, but was countered with hope, solidarity, cohesion, and gratitude for human kindness. Hence, through the analysis, we found support for those who argue that social cohesion from cultural trauma can act to coordinate individual behaviors and turn them into collective action (Narveson, 2002; Stilz, 2011). Numbers helped to construct the dramatic reality of the emergency. Thereby, calculative practices triggered people's emotional reactions to the emergency and contributed to shaping cultural trauma.

Italian popular culture and traditions do not directly pertain to the pandemic emergency but are grounded in society's texture. This cultural framing of collective identity relies on preexisting values and beliefs. The symbolic system of the Italian culture and traditions helped construct meanings and articulate the ideology underpinning the \#istayathome social movement (Buechler, 1993). Culture is the "milieu through which collective identities develop" (Saunders, 2008, p. 233), and our results demonstrate that Italian traditions acted like a glue holding the community together. These cultural factors were hard to vanquish and contributed to keeping the collective identity and cohesion of the social movement vivid for longer.

Overall, we observed that cultural trauma and cultural factors shape the collective identity to establish a collective responsibility sustaining social movement in response to 
emergencies. In turn, we found that calculative practices can trigger the emotional, moral and cognitive reactions shaping collective identity. Thereby, collective identity mediates the influence that calculative practices have on collective behaviors. As Miller and Rose (1990) highlight, political power acts on individuals. However, since individuality is often the result of massive societies, government, through calculative practices, can also influence popular culture (Jeacle, 2012). Popular culture and collective identity helped the government exercise their power through the support of mass mobilisation and collective action.

The Italian government's social campaign and use of social networks amplified this power quite effectively by using governance at a distance to its advantage. Different and autonomous actors (citizens and the Italian government) act toward the same goal because of a common interest - going out of the emergency (Jeacle, 2012). Since following the government's instructions was the only means to achieve this goal, the Italian government could govern citizens indirectly instead of imposing its direct force. Similarly to previous disasters (Kim and Hastak, 2018), the government used social networks to rule citizens' private space and exercise its power by propagating instructions and inducing collective behaviors. However, without the collective identity coming from the social movement, the Italian government could not have reached its aims in managing the emergency.

\subsection{Conclusion and theoretical contribution}

By exploring the collective identity and the elements underpinning \#istayathome, we offer novel theoretical and empirical knowledge of how government power affects people's culture and everyday lives. Conversely, we also show how collective actions can enhance government power. Hence, this study reveals the drivers mobilising collective behaviors when emergencies occur and enriches the accounting literature on the effects of calculative practices in managing disasters and emergencies. Our study reveals that the driver of collective identity and responsibility mobilising the social movement was culture-emotional, modern and traditional. People joined the social movement to amplify and extend the pervasive voice of the government. Yet, through their traumatic experience and shared culture, the Italian people found a sense of belonging that mobilised them to act together toward a common goal. The social movement that sprung up in response to the COVID-19 calamity comprised both active and passive collective behavior. As argued, social movements emblematically reflect a widespread effort toward change that involves many people with the same values, ideology and goals behaving in harmony. However, calculative practices also had a vital role in stimulating these feelings and mobilise people.

As collective identity results from people's cognitive, moral, and emotional connections with a broader community (Polletta and Jasper, 2001), we theorise that calculative practices acted as a technology stimulating these connections. Social movements are also rhetorical achievements and constitutive forces that cohere collective identity (Foust and Hoyt, 2018). Therefore, they need to be contextualised in their cultural, historical and political contexts while understanding the messages and expressions that mediate the creation of collective identity (Foust and Hoyt, 2018). We demonstrate that, by acting as rhetorical forces that influence the cognition, morals and emotions of individuals, calculative practices mediate the creation of collective identity, so gaining the power to influence collective behaviors.

Collective identity represents "an alternative to selective incentives in understanding why people participate" (Polletta and Jasper, 2001, p. 283). It can mobilise collective actions (Bennett and Segerberg, 2012; Brown et al., 2017). Yet, it can also explain some pleasures and obligations that persuade people to mobilise as an alternative to material incentives (Polletta and Jasper, 2001). Thus, collective identity provides a deeper understanding of the sociological structures that explain how calculative practices can change collective behaviors. Thereby, we contribute to the theory on the constituents that give rise to
Calculative practices and social movements

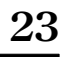


collective identity, their socialising effect and the success of calculative practices (Lai et al., 2014).

The Italian experience of COVID-19 demonstrates that calculative practices by governments can mesh with popular culture to turn the language of accounting into collective action. Thereby, this research also contributes to enriching the theoretical ground of the mutual interaction between popular culture and calculative practices (Jeacle, 2012). Jeacle (2012, p. 587) argues that, to unveil the power of accounting and calculative practices that shape people's social lives, the governmentality thesis in popular culture needs to extend "beyond the confines of the state or other formalities of government." This means examining the political power outside the political apparatus. It also means deploying the "technologies of government that enrol individuals in a network of interests such that they become selfregulating citizens" (Jeacle, 2012, p. 586). Social movement and collective identity theory offer a perspective for understanding how calculative practices influence collective behaviors, both directly and indirectly, and how they can bring informal networks of interest to life. Accordingly, social movements stand up as novel phenomena of interest for accounting research because it is through this lens that we can examine how the new power of informal networks is emerging and is being shaped (Heimans and Timms, 2018; McLaren and Appleyard, 2021). Thus, social movement theory opens up new avenues for future accounting research to examine the effects of accounting technologies on shaping collective behaviors.

This theoretical perspective helps explain the sociological components of how communities react to calculative practices by governments in a time of emergency and how the language of accounting was instrumental in conveying the gravity of the risk and fostering people to mobilise and join the movement. Thus, our study provides knowledge of the collective behaviors that governments and citizens apply in practice to manage emergencies and disasters.

\section{References}

Abdul Reda, A., Sinanoglu, S. and Abdalla, M. (2021), "Mobilizing the masses: measuring resource mobilization on Twitter", Sociological Methods and Research. doi: 10.1177/0049124120986197.

Ahmad, S., Connolly, C. and Demirag, I. (2021), "Testing times: governing a pandemic with numbers", Accounting, Auditing and Accountability Journal, Vol. 34 No. 6, pp. 1362-1375.

Ahrens, T. and Ferry, L. (2021), "Accounting and accountability practices in times of crisis: a Foucauldian perspective on the UK government's response to COVID-19 for England", Accounting, Auditing and Accountability Journal, Vol. 34 No. 6, pp. 1332-1344.

Alexander, J.C. (2016), "Culture trauma, morality and solidarity: the social construction of 'Holocaust' and other mass murders", Thesis Eleven, Vol. 132 No. 1, pp. 3-16.

Amenta, E., Caren, N., Chiarello, E. and Su, Y. (2010), "The political consequences of social movements", Annual Review of Sociology, Vol. 36, pp. 287-307.

Andrew, J., Baker, M. and Guthrie, J. (2021), “Accounting, inequality and COVID-19 in Australia”, Accounting, Auditing and Accountability Journal, Vol. 34 No. 6, pp. 1471-1483.

Antonelli, V., Bigoni, M., Funnell, W. and Cafaro, E.M. (2021), "Accounting for biosecurity in Italy under COVID-19 lockdown", Accounting, Auditing and Accountability Journal, Vol. ahead-of-p No. ahead-of-print. doi: 10.1108/AAAJ-07-2020-4674.

Baker, C.R. (2014), "Breakdowns of accountability in the face of natural disasters: the case of Hurricane Katrina”, Critical Perspectives on Accounting, Vol. 25 No. 7, pp. 620-632.

Bennett, W.L. and Segerberg, A. (2012), "The logic of connective action: digital media and the personalization of contentious politics", Information Communication and Society, Vol. 15 No. 5, pp. 739-768.

Blei, D.M., Ng, A.Y. and Jordan, M.I. (2003), "Latent Dirichlet allocation”, Journal of Machine Learning Research, Vol. 3 Nos 4-5, pp. 993-1022. 
Boedker, C., Chong, K.-M. and Mouritsen, J. (2019), "The counter-performativity of calculative practices: mobilising rankings of intellectual capital", Critical Perspectives on Accounting. doi: 10.1016/j.cpa.2019.102100.

Bratman, M.E. (2014), Shared Agency: A Planning Theory of Acting Together, Oxford University Press, Oxford.

Brewer, M.B. and Gardner, W. (1996), "Who is this 'We'? Levels of collective identity and self representations", Journal of Personality and Social Psychology, Vol. 71 No. 1, pp. 83-93.

Bright, J., Hale, S., Ganesh, B., Bulovsky, A., Margetts, H. and Howard, P. (2020), "Does campaigning on social media make a difference? Evidence from candidate use of Twitter during the 2015 and 2017 U.K. elections", Communication Research, Vol. 47 No. 7, pp. 988-1009, doi: 10.1177/ 0093650219872394.

Brown, M., Ray, R., Summers, E. and Fraistat, N. (2017), “\#SayHerName: a case study of intersectional social media activism”, Ethnic and Racial Studies, Vol. 40 No. 11, pp. 1831-1846.

Buechler, S.M. (1993), "Beyond Resource mobilization? Emerging trends in social movement theory", The Sociological Quarterly, Vol. 34 No. 2, pp. 217-235.

Cooper, C. and Lapsley, I. (2021), "Hillsborough: the fight for accountability", Critical Perspectives on Accounting, Vol. 79 No. September, 102077.

de Villiers, C. and Molinari, M. (2021), "How to communicate and use accounting to ensure buy-in from stakeholders: lessons for organizations from governments' COVID-19 strategies", Accounting, Auditing and Accountability Journal. doi: 10.1108/AAAJ-08-2020-4791.

Diani, M. (1992), “The concept of Social movement”, The Sociological Review, Vol. 40 No. 1, pp. 1-25.

Diani, M. (2000), "Social movement networks: virtual and real", Information, Communication and Society, Vol. 3 No. 3, pp. 386-401.

Diani, M. (2013), Networks and Social Movements, the Wiley-Blackwell Encyclopedia of Social and Political Movements, Blackwell Publishing, Oxford, doi: 10.1002/9780470674871.wbespm438.

Flesher Fominaya, C. (2010), "Collective identity in social movements: central concepts and debates", Sociology Compass, Vol. 4 No. 6, pp. 393-404.

Foust, C.R. and Hoyt, K.D. (2018), "Social movement 2.0: integrating and assessing scholarship on social media and movement", Review of Communication, Taylor \& Francis, Vol. 18 No. 1, pp. 37-55.

Gerbaudo, P. (2012), Tweets and the Streets: Social Media and Contemporary Activism, Pluto Press, London, doi: 10.2307/j.ctt183pdzs.

Goncharenko, G. (2021), "In the spotlight: rethinking NGO accountability in the \#MeToo era", Critical Perspectives on Accounting, No. xxxx, 102308.

Green, S.E. and Li, Y. (2011), "Rhetorical institutionalism: language, agency, and structure in institutional theory since Alvesson 1993", Journal of Management Studies, Vol. 48 No. 7, pp. 1662-1697.

Heimans, J. and Timms, H. (2018), New Power: Why Outsiders are Winning, Institutions are Failing, and How the Rest of Us Can Keep up in the age of Mass Participation, Pan Macmillan, Clerkenwell.

Hu, Y., Boyd-Graber, J., Satinoff, B. and Smith, A. (2014), "Interactive topic modeling", Machine Learning, Vol. 95 No. 3, pp. 423-469.

Huber, C., Gerhardt, N. and Reilley, J.T. (2021), "Organizing care during the COVID-19 pandemic: the role of accounting in German hospitals", Accounting, Auditing and Accountability Journal, Vol. 34 No. 6, pp. 1445-1456.

IlMattino (2020), Coronavirus, Conte: «Non cee più tempo, cambiamo le nostre abitudini», IlMattino, available at: https://www.ilmattino.it/video/primopiano/coronavirus_conte_non_c_piu_tempo_ cambiamo_le_nostre_abitudini-5102828.html.

Islam, M.A. and van Staden, C.J. (2018), "Social movement NGOs and the comprehensiveness of conflict mineral disclosures: evidence from global companies", Accounting, Organizations and Society, Vol. 65, July 2016, pp. 1-19. 
Jasper, J.M. (2011), "Emotions and social movements: twenty years of theory and research", Annual Review of Sociology, Vol. 37 No. 2011, pp. 285-303.

Jeacle, I. (2012), "Accounting and popular culture: framing a research agenda", Accounting, Auditing and Accountability Journal, Vol. 25 No. 4, pp. 580-601.

Jeacle, I. (2021), "Navigating netnography: a guide for the accounting researcher", Financial Accountability and Management, Vol. 37 No. 1, pp. 88-101.

Kassem, N. and Jackson, M. (2020), "Cultural trauma and its impact on the Iraqi Assyrian experience of identity", Social Identities, Vol. 26 No. 3, pp. 388-402.

Kim, J. and Hastak, M. (2018), "Social network analysis: characteristics of online social networks after a disaster", International Journal of Information Management, Vol. 38 No. 1, pp. 86-96.

Kozinets, R.V. (2002), "The field behind the screen: using netnography for marketing research in online communities", Journal of Marketing Research, Vol. 39 No. 1, pp. 61-72.

Lai, A., Leoni, G. and Stacchezzini, R. (2014), "The socializing effects of accounting in flood recovery", Critical Perspectives on Accounting, Vol. 25 No. 7, pp. 579-603.

Leoni, G., Lai, A., Stacchezzini, R., Steccolini, I., Brammer, S., Linnenluecke, M. and Demirag, I. (2021), "Accounting, management and accountability in times of crisis: lessons from the COVID-19 pandemic", Accounting, Auditing and Accountability Journal, Vol. 34 No. 6, pp. 1305-1319.

Levay, C., Jönsson, J. and Huzzard, T. (2020), "Quantified control in healthcare work: suggestions for future research", Financial Accountability and Management, Vol. 36 No. 4, pp. 461-478.

Matilal, S. and Adhikari, P. (2020), "Accounting in Bhopal: making catastrophe", Critical Perspectives on Accounting, Vol. 72, p. 102123.

McLaren, J. and Appleyard, T. (2021), "Social movements, identity and disruption in organizational fields: accounting for farm animal welfare", Critical Perspectives on Accounting, p. 102310.

Michelon, G., Rodrigue, M. and Trevisan, E. (2020), "The marketization of a social movement: activists, shareholders and CSR disclosure", Accounting, Organizations and Society, Vol. 80, p. 101074.

Miller, P. (2001), "Governing by numbers : why calculative practices matter”, Social Research, Vol. 68 No. 2, pp. 379-396.

Miller, P. and Rose, N. (1990), “Governing economic life”, Economy and Society, Vol. 19 No. 1, pp. 1-31.

Morris, A. (2000), "Reflections on social movement theory: criticisms and proposals", Contemporary Sociology, Vol. 29 No. 3, p. 445.

Narveson, J. (2002), “Collective responsibility”, The Journal of Ethics, Vol. 62 No. 1, pp. 179-198.

Padovani, E. and Iacuzzi, S. (2021), "Real-time crisis management: testing the role of accounting in local governments", Journal of Accounting and Public Policy, Vol. 40 No. 3, p. 106854.

Polletta, F. and Jasper, J.M. (2001), "Collective identity and social movements", Annual Review of Sociology, Vol. 27, May, pp. 283-305.

Power, M. (2004), "Counting, control and calculation: reflections on measuring and management", Human Relations, Vol. 57 No. 6, pp. 765-783.

Quarantelli, E.L. and Dynes, R.R. (1977), "Response to social crisis and disaster", Annual Review of Sociology, Vol. 3 No. 1, pp. 23-49.

Rao, H., Morrill, C. and Zald, M.N. (2000), "Power plays: how social movements and collective action create new organizational forms”, Research in Organizational Behavior, Vol. 22, pp. 237-281.

Sargiacomo, M. (2015), "Earthquakes, exceptional government and extraordinary accounting", Accounting, Organizations and Society, Vol. 42, pp. 67-89.

Sargiacomo, M., Ianni, L. and Everett, J. (2014), “Accounting for suffering: calculative practices in the field of disaster relief”, Critical Perspectives on Accounting, Vol. 25 No. 7, pp. 652-669.

Sargiacomo, M., Corazza, L., D’Andreamatteo, A., Dumay, J. and Guthrie, J. (2021), “COVID-19 and the governmentality of emergency food in the City of Turin", Accounting, Auditing and Accountability Journal, Vol. 34 No. 6, pp. 1457-1470. 
Saunders, C. (2008), "Double-edged swords? Collective identity and solidarity in the environment movement", British Journal of Sociology, Vol. 59 No. 2, pp. 227-253.

Stilz, A. (2011), "Collective responsibility and the state", Journal of Political Philosophy, Vol. 19 No. 2, pp. 190-208.

Sztompka, P. (2000), “Cultural trauma”, European Journal of Social Theory, Vol. 3 No. 4, pp. 449-466.

Taylor, D., Tharapos, M. and Sidaway, S. (2014), "Downward accountability for a natural disaster recovery effort: evidence and issues from Australia's Black Saturday", Critical Perspectives on Accounting, Vol. 25 No. 7, pp. 633-651.

Van Laer, J. and Van Aelst, P. (2010), "Internet and social movement action repertoires", Information, Communication and Society, Vol. 13 No. 8, pp. 1146-1171.

Vollmer, H. (2003), "Bookkeeping, accounting, calculative practice: the sociological suspense of calculation”, Critical Perspectives on Accounting, Vol. 14 No. 3, pp. 353-381.

Walker, S.P. (2014), "Drought, resettlement and accounting", Critical Perspectives on Accounting, Vol. 25 No. 7, pp. 604-619.

$\mathrm{Yu}$, A. (2021), "Accountability as mourning: accounting for death in the time of COVID-19", Accounting, Organizations and Society, Vol. 90, p. 101198.

\section{Corresponding author}

Matteo La Torre contacted at: matteo.latorre@unich.it
Calculative

practices and social

movements

For instructions on how to order reprints of this article, please visit our website:

www.emeraldgrouppublishing.com/licensing/reprints.htm

Or contact us for further details: permissions@emeraldinsight.com 